Kimberley Brownlee, Conscience and Conviction: The Case for Civil Disobedience. Oxford, Oxford University Press, 2012, 266 pp indexed. ISBN 978-0-19-959294-4, \$66 hardback.

Philosophers and political theorists with liberal democratic commitments tend to approach the topic of civil disobedience cautiously. They want to honour critique, dissent and individual conscience, but are hesitant about conscientious law-breaking. They worry in particular about a breakdown in respect for the rule of law and democratic decision-making. Concessions to civil disobedience they tend to hedge about with inhibiting conditions, such as an insistence that it be non-violent or require an acceptance of legal punishment.

Kimberley Brownlee's fine book displays no such nervousness and celebrates civil disobedience as a potentially vital element in a healthy liberal democracy. She confronts a wide range of the standard objections with confidence, care, clarity and argumentative rigour. She provides a nuanced and powerful defence of civil disobedience, in both its moral and legal aspects, and her book should become a key work to consult on the topic.

She states her overall objectives in the Introduction: "..my purposes in this book are, first to distinguish conscientious objection from conscience; second to defend the moral and legal merits of both conscientious disobedience and consciencedriven disobedience; and third to show that the disobedience that best falls under either of these two headings is non-evasive and communicative rather than private or evasive.” (p. 2).

One significant outcome of the pursuit of these objectives is that Brownlee attempts to subvert the common view in both academic and popular thinking that 
what is usually called conscientious objection is morally, politically and legally superior to civil disobedience. She argues, instead, that conscientious civil disobedience is superior since it has a public communicative aspect that provides a more positive contribution to democratic processes and community wellbeing. Conscientious objection, which she prefers to call "personal disobedience" is too selfcentred and deserves demotion, though it remains unclear just how far it must be downgraded. I shall return to this issue later.

The first of her general purposes requires some important distinctions. She treats conscientious disobedience as what she calls a "descriptive" notion and conscience-driven disobedience as "evaluative". Initially, this seems somewhat counter-intuitive, since we would normally think of the two terms as equivalent and both as evaluative since each seems to involve conscience and a call for moral respect. But Brownlee has a rather special conception of conscience such that not all conscientious action embodies the activity of conscience. This is understandable for conscientious actions that involve no moral element as with someone who is conscientious about their stamp collecting or conscientiously avoids cracks in the footpath. As Brownlee points out we do sometimes use "conscientious", "conscientiousness" and related terms to indicate a sort of fastidious, assiduous, concentrated attention to some task, whether it involves morality or not. She relies on this linguistic phenomenon to soften us up (as it were) for her stronger contrast of conscientious disobedience with conscience-driven disobedience even in the moral arena, since she argues that many forms of strongly morally motivated conscientious civil disobedience are not conscience-driven. To accomplish this, she needs a very rich concept of conscience that, as she admits, departs from most ordinary usage. 
She presents this revisionary concept most fully in Chapter 2, and sets her account against two opposing traditions that she calls objective and subjective. The heart of her position is the insistence that conscience is more than strong moral conviction; as she puts it: "conscience means not just taking morality seriously (conscientiousness), but also being genuinely, self-consciously morally responsive." (p.52). She emphasises a dynamic dimension to her concept of conscience whereby the moral agent is striving to implement an ideal of moral behaviour that involves a high degree of self-understanding. This striving aims at what is an objective but pluralistic moral reality. She rejects a religious explanation of conscience as "the voice of God" but also any amoral interpretation of the notion, as, for example, a merely psychological reality. For her, conscience requires the cultivation of "practical wisdom, virtue and objective moral integrity". (p.83). Clearly, much conscientious disobedience (hereafter, CD) is not driven by this idea of conscience, even where it is motivated by deeply felt moral conviction. Even so, Brownlee argues that both forms of $\mathrm{CD}$ are morally defensible and should receive a degree of legal protection.

One merit of this approach is that it not only allows for the fallibility of conscience (which any account must do) but also for its abiding value. A difficulty with it is that the picture of conscience it presents is at odds not only with much ordinary language, but more importantly perhaps her questing, self-scrutinising ideal involving a pluralistic moral reality seems ill at ease with what seems one crucial element in conscience-driven action, namely, the strength of its firm commitment to some value and the action flowing from it. Someone's categorical, unqualified rejection of slavery or torture can appear to lack the questing, openness to revision, that Brownlee's "conscience" apparently requires. Yet, those few intellectuals who stood out against slavery in the past and those other few who rejected the Western 
apologists for torture in the war on terror, were clearly conscience-driven, even if rigid in their (I believe correct) convictions. It is precisely this unfazed strength of conviction that often seems to indicate the presence of conscience.

In any case, this unusual account of conscience does not figure that significantly in the pursuit of her second and third purposes concerning the moral, political and legal claims about conscientious disobedience. Whether the disobedience is conscience-driven in her rich sense or simply seriously morally conscientious has some implications for some legal reactions to civil disobedience, but it doesn't matter for the issue of a moral right to civil disobedience or many of the legal consequences of admitting it. (She rightly distinguishes moral from legal rights, and considers the legal situation in the second part of the book.)

Central to her complex web of argument for the right to CD is what she calls a "humanistic principle of respect for our agency and dignity as persons". (p.7). Such respect honours the fact that we are "reasoning and feeling beings capable of forming deep moral commitments" but also that, in addition to satisfying consistency and universality conditions, "genuine moral conviction is essentially non-evasive and communicative." (p.7). Hence "society and law place undue pressure on us when they require us always to privilege the law before our deeply held moral convictions." (p.7). Moreover, such pressure is disadvantageous to both the objector's and society's own interests in the stabilising, democracy-promoting benefits of CD. Hence there arises a "demands-of-conviction" defence of the right to CD.

Her position is much stronger than the very limited rights to civil disobedience supported by many liberal philosophers. Joseph Raz, for instance, allows a full right to civil disobedience only in illiberal societies, arguing that such a right is based on the right to participate in political decision-making, and this is already secured in 
liberal societies. He allows it in liberal societies only where it is genuinely justifiable or obligatory, rather than only conscientiously believed to be so. John Rawls allows the right even in a "nearly just society" but restricts it to those who are responding to a substantial and clear injustice, acting as "a last resort", and acting in concert with other minority groups. In addition, Rawls requires (by definition) that civil disobedience be non-violent, a condition that many would endorse for legitimate civil disobedience, even if not as a definitional feature. A further common philosophical and popular view is the moral requirement that civil disobedients (however justified) must accept or embrace punishment for their actions.

Brownlee rejects nearly all of this - the possible exception is the last resort condition that she seems to accept in some form while allowing for its vagueness (see p. 44-5). She thinks that a moral right of civil disobedience can exist in both liberal democratic regimes and illiberal ones, that it can be (moderately) violent, and that it is morally tolerable on behalf of even profoundly mistaken causes, as long as it satisfies certain self-restrained non-evasive and communicative conditions. The non-evasive conditions require that the civil disobedient should accept the risks of her open defiance, and the communicative condition requires that she should seek to engage the community, or significant parts of it, in dialogue about the cause at issue. The dialogue condition implies that there will usually be constraints on the actions of the civil disobedient, such as avoiding any form of violence that would seriously imperil dialogue, though, as she points out, the civil disobedient need not intend to communicate civilly with everyone. She may be aiming at particular groups capable of influencing public policy or law reform.

Brownlee's responses to apparent difficulties in her position are discussed most fully in connection with the idea that the law should recognise the moral right to 
$\mathrm{CD}$ by leniency in response to the violations. These responses are also defences of the moral right itself, and are connected to her argument for the power of moral roles to override legal and institutional roles. The first objection she calls the Strategic Action Problem, the second is The Democracy Problem which in its turn has three subdivisions: an epistemic argument, an anti-paternalist argument, and a procedural fairness argument.

I found the primary form of the strategic action problem pretty puzzling since it seems to consist in accusing the $\mathrm{CD}$ of having further aims than protesting a particular law, and thereby breaching the humanism principle. So, even the indirect $\mathrm{CD}$ who breaks an innocuous law in order to bring attention to her objections to another law is supposed to sin against the respect for "our agency and dignity as persons". Brownlee has some arguments against this, but seems to me to concede too much to this style of objection. Kant is in the background here, but the Kantian imperative is not against treating people as means, but rather as means only, so having strategic purposes is not per se a problem. It all depends on what they are and how they relate to basic respect for the persons in question. A CD who breaks a law in order to bring attention to its perceived injustice is surely not disbarred from the right to $\mathrm{CD}$ by having the further purpose of trying to help change the government that promulgated the law.

The more serious difficulties, and more commonly presented ones, are those from supposed dangers to democracy. The epistemic objection is that the $\mathrm{CD}$ ignores the fact that "the legislature is better placed than individual citizens are to account for all of the reasons that bear on the right guidance to follow." (p.174). She replies to the epistemic objection in three ways. First, the objection is dubious on empirical grounds, second it is not only a matter of who is better placed for access to the facts, 
but also who has the better motivation to acknowledge the facts, and third, even if the legislature is generally epistemically best placed they can benefit from pointed minority opposition "to ensure that they remain alive to all of the salient reasons, given the competing pressures they face." (p.176). She seems to me palpably correct on all three points, but one might amplify the responses by pointing out several things about the epistemic authority of government. First, even if we attach particular importance to institutional and communal authority, an individual's membership of many institutions and communities, other than the government and nation, means that a given individual confronts epistemic authority from several sources and needs to resolve possibly divergent information from each of them. This is further support for Brownlee's claim that certain experts can be in a better epistemic position than government decision makers; she mentions environmentalists and soldiers regarding environmental protection and warfare respectively, but might have mentioned skilled investigative journalists, international lawyers, ex-diplomats, and many more, as well as those who rightly respect some of these authorities.

A second point is that Brownlee's first critique of the epistemic objection tends to focus on the reliability of governmental factual information but there is an important issue about whether legislators are better placed than ordinary citizens regarding moral information. Philosophers will disagree about the idea of moral facts and expertise about them, but there is surely room for the idea of better and worse moral views, however we parse the idea meta-ethically. In the case of war, moral views are often at the heart of debate and of conscientious objection and civil disobedience. If you think that there is such a thing as moral authority or expertise, then it is no more likely to be found in a democratic legislature than in many other places in the community (or various sub-communities); if you believe in moral 
authority or expertise but not in its communal variety then again there is no principled superiority of state authority to private judgement; if you do not believe in moral authority or expertise at all, then there is even less reason to defer to the moral backing that the rulers have for their decision without close personal attention to its basis.

A related issue is that of ideological outlook. Decisions about waging war, for example, that are primarily informed by some simple version of political realism (national interest above all and morality mustn't intrude) or by crude religious fundamentalism or neo-con ideology cannot be assimilated easily to a model of superior information on the part of rulers.

Brownlee's second reply focuses on the mix of dubious motivations that can influence the epistemic credentials of rulers, and her third reply cites a familiar Millian claim that even false judgements firmly held and proclaimed in opposition to the prevailing true view can serve an important function in clarifying that view, in requiring better reasons to be produced in support of it, and even modifying aspects of it. So, even if there were a superior quality of epistemic access for rulers, there are good democratic reasons for its contestation and opposition by CD.

The second form of the democratic challenge, the anti-paternalist challenge, at its strongest, is also epistemic. Brownlee doesn't acknowledge this, but she thinks the argument views $\mathrm{CD}$ as disrespectful of fellow citizens because "we assume that we know better than other members of our community... we insult our fellow citizens by privileging our own judgment above that of the democratic process." (pp174-75) Yet this need not be an illegitimate epistemic assumption since there is no reason to believe that democratic processes guarantee knowledge, and we do not disrespect other people or democratic processes by standing firm on our own different beliefs 
(indeed it might be disrespectful not to declare such beliefs and act upon them). One may honour the development of the democratic process by spirited opposition to its current manifestations, including conscientious law-breaking.

Brownlee's arguments here defend the moral right of conscientious disobedience, but also, amongst other considerations, they are arguments for specific legal recognitions of $\mathrm{CD}$. The demands-of-conviction argument provides an excusatory defence of all $\mathrm{CD}$, while the necessity defence provides a justificatory defence of conscience-driven disobedience (in her strong sense of conscience). Much of the impact of the latter depends on its being unavailable to those disobedients who violate others' basic needs and rights, so the excusatory defence may be available for Nazis, anti-gay law breakers, and so on under some conditions where a necessity defence is unavailable. More generally, Brownlee argues for a less punitive or nonpunitive legal response to $\mathrm{CD}$ behaviour. She rejects the idea that the law cannot recognise competing values and proposes a "modesty of law" thesis whereby various values beyond the law's scope may have a legitimate role in constraining the action of the law.

There is much other rich material in the book to discuss, beyond what I can engage with here, such as: a distinction between direct and indirect conscientious objection; the idea of "assistive disobedience" as contrasted with civil disobedience; the concept of moral role and its connection and contrast with institutional or legal role, and the former's potential to override the latter; the complex relations between freedom of thought and freedom of expression; and the best philosophical theory of the nature and justification of punishment.

I will conclude with a qualified caveat on her relegation of conscientious (or personal) objection/disobedience to an inferior place behind CD. I think she is right to 
elevate $\mathrm{CD}$ to a better place than it occupies in so much philosophical and political discussion. This is a significant contribution, but I am cautious about her determination to tumble personal objection so far down the scale. Her main reason for doing this is her insistence that personal objection/disobedience often fails the tests of non-evasiveness and always fails the test of dialogue. (see p.160). But this is clearly too narrow a view of much that is usually called conscientious objection. As she notes, in a brief footnote, what is often called selective conscientious objection to warfare is usually communicative in the required way since such objectors intend to persuade others of the immorality of a particular war. Nor, given the relaxed interpretation Brownlee gives of the communicative condition in response to objections in Chapter 1, are most total pacifists usually indifferent to the dialogue requirement. In addition, lots of these objectors, especially those objecting to war service, will be non-evasive. Thus many "personal objectors or disobedients" should be morally and legally on a par with her conscientious civil disobedients. Moreover, there remains a question whether many of those who aren't on a par should have no moral or legal basis for better treatment than criminals, and this is an issue about which Brownlee displays uncharacteristic vagueness.

But such qualifications aside, Brownlee's book makes an original contribution to an important topic that she discusses with persuasive intelligence and careful argument.

\section{C.A.J Coady}

University of Melbourne 
Professor C.A.J. Coady

University of Melbourne 


\section{University Library}

\section{- M M I N E R VA A gateway to Melbourne's research publications}

Minerva Access is the Institutional Repository of The University of Melbourne

Author/s:

Coady, CAJ

Title:

Conscience and Conviction: The Case for Civil Disobedience

Date:

2016-06-01

Citation:

Coady, C. A. J. (2016). Conscience and Conviction: The Case for Civil Disobedience. JOURNAL OF VALUE INQUIRY, 50 (2), pp.501-506. https://doi.org/10.1007/ s10790-015-9502-0.

Persistent Link:

http://hdl.handle.net/11343/283195 